\title{
A New Gene for Flower Color Pattern, White Banner $(w b)$, in Progeny of an Interspecific Hybrid between Common and Scarlet Runner Beans
}

\author{
Mark J. Bassett ${ }^{1}$ \\ Vegetable Crops Department, IFAS, University of Florida, Gainesville, FL 32611 \\ Additional index words. plant breeding, snap bean
}

\begin{abstract}
A new gene for flower color pattern, designated white banner (WB), appeared in material derived from the cross 'Harvester' snap bean (Phaseolus vulgaris L.) $\times$ Plant Introduction (PI) accession 273666 of scarlet runner bean (P. coccineus $\mathrm{L}$.). The WB character has a white banner petal and pale violet wings (veronica-violet 639/2). The inheritance of the mutant was studied in crosses involving dry bean breeding line 5-593, which has bishops-violet (wild-type) flowers, and genetic stocks $v \mathrm{BC}_{2}$ 5-593 (white flowers) and blu $\mathrm{BC}_{2}$ 5-593 (blue flowers). Segregation in $\mathrm{F}_{2}$ and $\mathrm{F}_{3}$ progenies from the cross $v \mathrm{BC}_{2} 5-593 \times \mathrm{WB}$ supported the hypothesis that $\mathrm{WB}$ is controlled by a single recessive gene that is nonallelic with the $V$ locus. An allelism test with blu $\mathrm{BC}_{2}$ 5-593 gave evidence that $\mathrm{WB}$ is not allelic with the blu locus. The gene symbol $w b$ is proposed for the gene producing $\mathrm{WB}$.
\end{abstract}

The genetics of flower color in common bean was reviewed recently by Leakey (1988) in a book chapter, which has helpful illustrations [after Prakken (1972)] of color patterns on the wing and banner petals. [Note: Leakey has pointed out a typographical error in the diagram of his paper: "Amended genotype proposed" for the all-white flower type code 1 should read $p p T R k, P t t R k$, or $P T r k r k$.] In this paper, all color names and numeric designations are taken from the Horticultural Colour Chart of the Royal Horticultural Society (1938). A recessive allele at either $P$ or Twill produce an all-white flower. In the presence of $P$ and $T$, the $V$ locus can express a series of colors (wing petal only): $V / V$ gives bishopsviolet, $V / v$ gives cobalt-violet, $v^{\text {lae }} / v^{\text {lae }}$ gives rose-purple, and $v / v$ gives white (Bassett et al., 1990). Either $P /-T /-v^{\text {lae }} / v$ lae or $P /-T /$ $v / v$ with $r k^{d} / r k^{d}$ gives red veins in the wing petals (Prakken, 1972). In the presence of $P$ and $T$ with $v, R$ st/-gives a red-tipped banner petal (Prakken, 1972). The interactions of Sal (from P. coccineus) with $V$ and $v$ are fully described by Bassett et al. (1990). Recently, an induced mutant for blue (methyl-violet) flower color was reported to be controlled by blu/blu (Bassett, 1992).

This paper presents evidence for the inheritance of a genetic variant for flower color pattern, designated "white banner," that appeared in segregating progenies derived from an interspecific hybrid.

\section{Materials and Methods}

In 1977, a cross was made between the 'Harvester' snap bean $(p / p)$ and the $P$. coccineus Plant Introduction (PI) accession 273666, which has vine habit and scarlet flower color. Scarlet flower color is probably due to $\mathrm{Sal} A m v$ (my unpublished data). In the resulting $\mathrm{F}_{2}$ population, selections were made for bush (determinate) habit. Two such selections, designated 273666 \#12 (white flowers with red veins, $\left.P /-T /-v l v r k^{d} / r k^{d}\right)$ and 273666 \#23 (camellia-rose flowers, $\mathrm{P} / \mathrm{T}$ - T/ $\mathrm{Sal} / \mathrm{Sal} \mathrm{v} / \mathrm{v}$ ) were crossed.

Breeding line 5-593 has determinate plant habit, bishops-violet flowers $(P T \mathrm{~V})$, and shiny black seeds. A genetic stock, $v \mathrm{BC}_{2} 5-$

Received for publication 5 June 1992. Accepted for publication 2 Mar. 1993. Florida Agricultural Experiment Station Journal Series no. R-02336. The cost of publishing this paper was defrayed in part by the payment of page charges. Under postal regulations, this paper therefore must hereby be marked advertisement solely to indicate this fact.

${ }^{1}$ Professor.
593, was produced by backcrossing the recessive allele $\mathrm{v}$ into the 5-593 recurrent parent, giving white flowers $(P T v)$ and mineral brown seeds. The complete seed coat color genotype of 5-593 is $P$ $T$ Mar C $D J$ G $B V R k$ (my unpublished data).

In 1988, the breeding line 5-593 was crossed with $\mathrm{F}_{1}(273666$ $\# 23 \times 273666$ \#12), which probably had the genotype P/P T/T Sal/ sal Am/am $v / v R k / r k^{d}$ and may have been heterozygous for a gene controlling white banner. The $\mathrm{F}_{2}$ population was planted in the field in Spring 1989. Selections were made for segregants with unique flower colors: white banner petals and pale violet wings (Veronica-violet 639/2). This new flower color pattern was named white banner (WB). In 1989, crosses were made between the genetic stock $v \mathrm{BC}_{2}$ 5-593 and $\mathrm{F}_{3}$ progeny of the $\mathrm{WB}$ selections. In Spring 1990, $F_{2}$ progenies of the resulting $F_{1}$ plants were planted in separate field plots, 90-717 through 90-732 and 90-740 through 90-744.

In 1990, the genetic stock blu $\mathrm{BC}_{2}$ to 5-593 (P T V blu) (Bassett, 1992) was crossed with an $\mathrm{F}_{3}$ selection from 90-718 with WB V/ $v$ flowers. In Spring 1991, $\mathrm{F}_{2}$ progenies from the resulting $\mathrm{F}_{1}$ plants were planted in separate field plots, 91-132 through 91-137. In Fall 1990 , remnant seed of $F_{2}$ stock $90-718$ were planted in the greenhouse, and $\mathrm{F}_{3}$ seed were produced on 39 unselected $\mathrm{F}_{2}$ progeny. The $F_{3}$ seed were planted in the field in Spring 1991 in plots 91-601 through 91-639. The second backcross to 5-593 was made by the cross 5-593 $\times \mathrm{F}_{3}$ 90-718 WB flowers. The $\mathrm{BC}_{2}-\mathrm{F}_{2}$ seed were planted in the field in Spring 1991 in plots 91-640 through 91-642.

Classification for flower color was made in all the segregating progenies planted in the field in 1990 and 1991, and notes were made on the flower color of all parental material and $F_{1}$ progeny described above.

\section{Results and Discussion}

The cross $v \mathrm{BC}_{2} 5-593 \times \mathrm{F}_{3}$ WB flower segregants produced $\mathrm{F}_{1}$ progeny with cobalt-violet flower color, which is interpreted as a nonallelic response showing the genotype $V / v$. The hypothesis of nonallelism between the $V$ locus and the locus controlling the WB character is supported by $\mathrm{F}_{2}$ segregation for three flower color classes (Table 1). Two of these classes were parental and the third was wild type, which is interpreted as a two-factor segregation. The $F_{2}$ populations were tested for goodness of fit to a 9:3:4 segregation ratio, and 19 of the 20 populations gave a satisfactory 
Table 1. Segregation for flower color in the $\mathrm{F}_{2}$ from the cross $v \mathrm{BC}_{2}$ 5-593 $x \mathrm{~F}_{3}$ white banner flower segregants.

\begin{tabular}{|c|c|c|c|c|c|}
\hline \multirow[b]{2}{*}{ Plot no. } & \multicolumn{3}{|c|}{ Segregation classes and genotypes } & \multirow[b]{2}{*}{$\chi^{2}(9: 3: 4)$} & \multirow[b]{2}{*}{$P$ value } \\
\hline & $\begin{array}{l}\text { Wild type } \\
(V /-W b /-)\end{array}$ & $\begin{array}{c}\text { White } \\
\text { banner } \\
(V /-w b / w b)\end{array}$ & $\begin{array}{c}\text { White } \\
\text { flower } \\
(v / v-/-)\end{array}$ & & \\
\hline$\overline{90-717}$ & 31 & 4 & 13 & 3.45 & 0.18 \\
\hline $90-718$ & 30 & 7 & 12 & 0.74 & 0.69 \\
\hline $90-719$ & 27 & 7 & 16 & 1.627 & 0.44 \\
\hline $90-721$ & 27 & 4 & 12 & 2.519 & 0.28 \\
\hline $90-722$ & 35 & 4 & 8 & 6.598 & 0.04 \\
\hline $90-723$ & 23 & 6 & 19 & 5.676 & 0.06 \\
\hline $90-724$ & 29 & 5 & 15 & 2.60 & 0.27 \\
\hline $90-725$ & 32 & 7 & 8 & 2.74 & 0.25 \\
\hline $90-726$ & 32 & 3 & 11 & 5.14 & 0.08 \\
\hline $90-727$ & 27 & 3 & 16 & 5.478 & 0.07 \\
\hline $90-728$ & 24 & 3 & 10 & 2.784 & 0.25 \\
\hline $90-729$ & 25 & 4 & 13 & 2.582 & 0.28 \\
\hline $90-730$ & 14 & 4 & 2 & 2.489 & 0.29 \\
\hline $90-731$ & 27 & 3 & 10 & 3.60 & 0.17 \\
\hline $90-732$ & 27 & 8 & 11 & 0.116 & 0.94 \\
\hline $90-740$ & 24 & 6 & 12 & 0.667 & 0.72 \\
\hline $90-741$ & 23 & 6 & 16 & 2.921 & 0.23 \\
\hline $90-742$ & 31 & 5 & 9 & 3.128 & 0.21 \\
\hline $90-743$ & 27 & 8 & 10 & 0.274 & 0.87 \\
\hline $90-744$ & $\underline{20}$ & $\underline{5}$ & $\underline{13}$ & 2.012 & 0.37 \\
\hline Totals & $5 \overline{35}$ & 102 & 236 & 28.623 & $<0.001$ \\
\hline Expected $^{y}$ & 491.06 & 163.69 & 218.25 & & \\
\hline
\end{tabular}

${ }^{2}$ Wild-type colors include bishops-violet $(V / V)$, cobalt-violet $(V / v)$, and (in some plots) various red colors produced by interactions of $S a l$ and $V, v$ (Bassett et al., 1990).

yThe expected values are based on the segregation ratio 9:3:4.

fit (Table 1). On the basis of these results and other data presented below, the gene symbol $w b$ is adopted for the WB character. However, when the data were combined and tested, the $\chi^{2}(9: 3: 4)$ $=28.623, P<0.001$. An examination of the deviations from expected values indicates that there was a large deficiency of WB

Table 2. Genetic model for flower color segregation in $F_{2}$ progeny from crosses between $v W b$ and $V w b$ and the expected segregation in $\mathrm{F}_{3}$ progeny tests of each genotype in the $\mathrm{F}_{2}$.

\begin{tabular}{|c|c|c|c|}
\hline $\mathrm{F}_{2}$ genotypes & $\begin{array}{c}\text { Fre- } \\
\text { quency }^{z}\end{array}$ & $\mathrm{~F}_{2}$ phenotypes & $\begin{array}{l}\text { Expected }{ }^{y} \text { segre- } \\
\text { gation in } \mathrm{F}_{3}\end{array}$ \\
\hline$\overline{W b / W b V / V}$ & 1 & Bishops-violet (BV) & True-breeding for $\mathrm{BV}$ \\
\hline$W b / W b V / v$ & 2 & Cobalt-violet (CV) & $3(\mathrm{BV}+\mathrm{CV}): 1$ white \\
\hline$W b / W b v / v$ & 1 & White & True-breeding for white \\
\hline$W b / w b V / V$ & 2 & Bishops-violet (BV) & 3BV:1 whitebanner(WB) \\
\hline$W b / w b V / v$ & 4 & Cobalt-violet (CV) & $\begin{array}{l}9(\mathrm{BV}+\mathrm{CV}): 3 \mathrm{WB}: 4 \\
\text { white }\end{array}$ \\
\hline$W b / w b v / v$ & 2 & White & True-breeding for white \\
\hline$w b / w b V / V$ & 1 & White banner (WB) & True-breeding for WB \\
\hline$w b / w b V / v$ & 2 & White banner (WB) & $3 \mathrm{WB}: 1$ white \\
\hline$w b / w b v / v$ & 1 & White & True-breeding for white \\
\hline
\end{tabular}

${ }^{\mathrm{z}}$ Each value is the numerator $(\mathrm{n})$ of the expected frequency $(\mathrm{n} / 16)$ in the $\mathrm{F}_{2}$, in which the expected ratio of phenotypic classes is $9(\mathrm{BV}+\mathrm{CV}): 3$ WB:4 white.

YThe expected ratio of segregation classes in the $F_{3}$ (from random $F_{2}$ plants) is 1 true-breeding for $\mathrm{BV}: 2[3(\mathrm{BV}+\mathrm{CV}): 1$ white $]: 2(3 \mathrm{BV}: 1$ white banner $): 4[9(\mathrm{BV}+\mathrm{CV}): 3 \mathrm{WB}: 4$ white $]: 1$ true-breeding for WB $: 2$ (3 WB:1 white) : 4 true-breeding for white. segregants (Table 1). An analysis of segregation at the $V$ and $W b$ loci gave the following results: For the $V /-$ and $v / v$ classes, the segregation was 671 and 247 , respectively, and $\chi^{2}(3: 1)=1.779, P$ $=0.18$. For the $W b /-$ and $w b / w b$ classes, the segregation was 807 and 111 , respectively, and $\chi^{2}(3: 1)=81.582, P<0.001$. Thus, segregation was normal at the $V$ locus, but there is reduced transmission of the recessive allele at the $W b$ locus. Because the $w b$ allele appears to have originated from the $P$. coccineus PI accession 273666, it is possible that $w b$ is linked to genes that give poor transmission. Disturbed ratios of this type are common in interspecific crosses between P. vulgaris and P. coccineus (Smartt, 1970).

Some of the $\mathrm{F}_{2}$ populations also segregated for $\mathrm{Sal}$, but those data were omitted to avoid unnecessary complication of the presentation (Table 1); i.e., the segregation at $w b$ and $V$ could be classified in the presence of Sal without reference to Sal. The interaction of $S a l$ and $w b V$ produces a unique phenotype. The banner petal is variable in color (perhaps due to Sal/Sal vs. Sal/sal); heliotrope $636 / 1,2$, or 3 ; and the wings are heliotrope $636 / 2$ or cobalt-violet 634/2. These hues are slightly redder than rosepurple because of the action of Sal.

Although the combined data in Table 1 show a disturbed 9:3:4 ratio, not all of the contributing progenies give high $\chi^{2}$ values. If the disturbance is due to linked genes from the $P$. coccineus parent PI 273666 , then $F_{2}$ progenies with $\chi^{2}$ values $<1$ may have broken the linkage between $w b$ and these genes. Plot 90-718 has $\chi^{2}=0.74$, and, therefore, the hypothetical linkage may have been broken in this stock. To test this idea, remnant seed were grown in the greenhouse and the progeny were classified for flower color. When the new data were added to that in Table 1, the combined data were 53 plants with $V /-W b /$ - flowers, 16 with $V /-w b / w b$ flowers, and 20 with $v / v-/-$ flowers, which gives $\chi^{2}(9: 3: 4)=$ $0.428, P=0.81$. The goodness of fit to the ratio improves with added sample size. It is concluded that the parent of plot 90-7 18 is free of the factors producing the disturbed segregation in Table 1.

To test the hypothesis that WB flower color is controlled by a single recessive gene, $w b, \mathrm{~F}_{3}$ progeny tests were made of the $39 \mathrm{~F}_{2}$ plants grown from remnant seed of 90-718. The expected frequencies of the various segregation classes in $\mathrm{F}_{2}$ and $\mathrm{F}_{3}$, based on a twofactor model, are presented in detail (Table 2). All the various expected $\mathrm{F}_{3}$ segregation classes were observed, and there was good agreement with their expected frequencies (Table 3). The combined data involving the two types of $\mathrm{F}_{3}$ progenies segregating at the $W b$ locus gave acceptable fits to the expected ratios, but the probability values are somewhat low, viz., 0.21 and 0.12 . This raises some doubt about the $W b$ locus being entirely free of the hypothetical linked genes or pleiotropic effects of $w b$ that may reduce transmission somewhat.

A second backcross was made between 5-593 and segregants carrying wblwb $V / v$ in $\mathrm{BC}_{1}$ to 5-593. The three resulting $\mathrm{F}_{2}$ progenies all segregate for $\mathrm{v}$, and they give no indication of any disturbance in the segregation for $w b$ (Table 4). There is no support for the possibility that $w b$ may have pleiotropic effects that reduce its transmission rate with respect to the rate for the wild-type allele $W b$.

A stock with WB flowers was also crossed to the blue flower marker character to test for allelism. The $F_{1}$ progeny had either cobalt-violet or bishops-violet flowers, which is interpreted as an indication of nonallelism. The $\mathrm{F}_{2}$ progeny from the allelism test give a good fit either a two-factor segregation ratio, involving only $w b$ and $b l u$, or a three-factor segregation ratio involving $w b$, blu, and v (Table 5). Clearly, $w b$ is nonallelic with blu.

In summary, the WB character is confirmed to be controlled by a single recessive gene that is nonallelic with either $V$ or $b l u$. The 
Table 3. Segregation for bean flower color in $F_{3}$ progeny tests of 39 unselected $\mathrm{F}_{2}$ plants from the cross $W b v \mathrm{BC}_{2} 5-593 \times \mathrm{F}_{3}$ 9-523-4 \#1 $w b V$ (from remnant seed of 90-718, Table 1 ).

\begin{tabular}{|c|c|c|c|c|c|c|c|}
\hline \multirow[b]{2}{*}{$\begin{array}{l}\text { Plot } \\
\text { no. }\end{array}$} & \multirow[b]{2}{*}{$\underset{\text { parent }}{\mathrm{F}_{2}}$} & \multicolumn{3}{|c|}{ Classification of $F_{3}$ progeny ${ }^{z}$} & \multirow[b]{2}{*}{$\begin{array}{l}\text { Ratio } \\
\text { tested }\end{array}$} & \multirow[b]{2}{*}{$\begin{array}{c}\chi^{2} \\
\text { value }\end{array}$} & \multirow[b]{2}{*}{$\begin{array}{c}P \\
\text { value }\end{array}$} \\
\hline & & $\begin{array}{c}\text { Violet }^{\mathrm{y}} \\
(V /-W b /-)\end{array}$ & $\begin{array}{c}\text { White } \\
\text { banner } \\
(V /-w b / w b)\end{array}$ & $\begin{array}{l}\text { White } \\
(v / v-/-)\end{array}$ & & & \\
\hline$\overline{1-634}$ & $V W b$ & 40 & & & & & \\
\hline $1-639$ & & 38 & & & & & \\
\hline $1-618$ & $V / v W b$ & 46 & & 16 & $3: 1$ & 0.022 & 0.88 \\
\hline $1-619$ & & 58 & & 13 & $3: 1$ & 1.695 & 0.19 \\
\hline $1-620$ & & 50 & & 22 & $3: 1$ & 1.185 & 0.28 \\
\hline $1-625$ & & 54 & & 19 & $3: 1$ & 0.041 & 0.84 \\
\hline $1-626$ & & 54 & & 14 & $3: 1$ & 0.706 & 0.40 \\
\hline $1-629$ & & 57 & & 14 & $3: 1$ & 1.056 & 0.30 \\
\hline $1-630^{x} 1$ & $V W b / w b$ & 54 & 21 & & $3: 1$ & 0.360 & 0.55 \\
\hline $1-631^{x}$ & & 26 & 10 & & $3: 1$ & 0.148 & 0.70 \\
\hline $1-632^{x}$ & & 31 & 5 & & $3: 1$ & 2.370 & 0.12 \\
\hline $1-633^{x}$ & & 30 & 8 & & $3: 1$ & 0.316 & 0.57 \\
\hline $1-635^{x}$ & & 31 & 7 & & $3: 1$ & 0.877 & 0.35 \\
\hline $1-636^{x}$ & & 28 & 9 & & $3: 1$ & 0.009 & 0.92 \\
\hline $1-637^{x}$ & & 32 & 6 & & $3: 1$ & 1.719 & 0.19 \\
\hline $1-638^{x}$ & & 30 & 8 & & $3: 1$ & 0.316 & 0.57 \\
\hline $1-617^{w}$ & $V /-W b /-$ & 34 & 11 & 13 & $9: 3: 4$ & 0.215 & 0.90 \\
\hline $1-621^{w}$ & & 43 & 11 & 18 & $9: 3: 4$ & 0.619 & 0.73 \\
\hline $1-622^{w}$ & & 41 & 17 & 15 & $9: 3: 4$ & 1.381 & 0.50 \\
\hline $1-623^{w}$ & & 43 & 7 & 19 & $9: 3: 4$ & 3.354 & 0.19 \\
\hline $1-624^{w}$ & & 45 & 10 & 20 & $9: 3: 4$ & 1.444 & 0.49 \\
\hline $1-627^{w}$ & & 41 & 9 & 16 & $9: 3: 4$ & 1.340 & 0.51 \\
\hline $1-628^{w}$ & & 45 & 11 & 13 & $9: 3: 4$ & 2.324 & 0.31 \\
\hline $1-603$ & $V w b$ & & 31 & & & & \\
\hline $1-609$ & & & 38 & & & & \\
\hline $1-601$ & $V /-w b$ & & 22 & 8 & $3: 1$ & 0.044 & 0.83 \\
\hline $1-602$ & & & 22 & 12 & $3: 1$ & 1.922 & 0.17 \\
\hline $1-604$ & & & 22 & 8 & $3: 1$ & 0.044 & 0.83 \\
\hline $1-605$ & & & 31 & 8 & $3: 1$ & 0.419 & 0.52 \\
\hline $1-606$ & & & 28 & 9 & $3: 1$ & 0.009 & 0.92 \\
\hline $1-607$ & & & 28 & 10 & $3: 1$ & 0.035 & 0.85 \\
\hline $1-608$ & & & 25 & 9 & $3: 1$ & 0.039 & 0.84 \\
\hline $1-610$ & $v / v-1-$ & & & 29 & & & \\
\hline $1-612$ & & & & 29 & & & \\
\hline $1-613$ & & & & 29 & & & \\
\hline $1-614$ & & & & 29 & & & \\
\hline $1-615$ & & & & 29 & & & \\
\hline $1-616$ & & & & 26 & & & \\
\hline
\end{tabular}

${ }^{\text {zFor the }} \chi^{2}$ test for the goodness of fit of the $\mathrm{F}_{3}$ segregation classes to the expected (Table 2$)$ the $\chi^{2}(1: 2: 2: 4: 1: 2: 4)=4.897, P=0.56$.

YThe violet flower class includes both bishops-violet $(V / V)$ and cobaltviolet $(V / v)$.

${ }^{x}$ For the progenies segregating for violet and white banner flowers the totals were 262 and 74 , respectively, and the $\chi^{2}(3: 1)=1.587, P=0.21$.

wFor the progenies segregating for violet, white banner, and white flowers the totals were 292,76 , and 114 , respectively, and the $\chi^{2}(9: 3: 4)=4.244$, $P=0.12$.

flower type of $w b$ is distinguished easily from wild-type and all other flower color variants and, thus, makes a valuable addition to the marker genes available in common bean.

The relationship of $w b$ to $r k^{d}$ has not been explored in the experiments described above, and some discussion of the effects of $r k^{d}$ on flower color pattern is necessary. The genotype $v r k^{d}$ produces flowers with a white banner petal and wing petals of pure white, except for very fine red veins (Leakey, 1988; Prakken,
Table 4. Segregation for flower color in the $\mathrm{F}_{2}$ from the cross 5-593 $\times w b$ $V / v \mathrm{BC}_{1} 5-593$.

\begin{tabular}{|c|c|c|c|c|c|}
\hline \multirow[b]{2}{*}{ Plot no. } & \multicolumn{3}{|c|}{ Flower color classes } & \multirow[b]{2}{*}{$\chi^{2}(9: 3: 4)$} & \multirow[b]{2}{*}{$P$ value } \\
\hline & Violet $^{2}$ & $\begin{array}{c}\text { White } \\
\text { banner }\end{array}$ & White & & \\
\hline $1-640$ & 20 & 9 & 9 & 0.608 & 0.74 \\
\hline $1-641$ & 21 & 5 & 9 & 0.467 & 0.79 \\
\hline $1-642$ & $\underline{22}$ & $\underline{6}$ & $\underline{10}$ & 0.222 & 0.90 \\
\hline MISSING? & 63 & 20 & 28 & 0.039 & 0.98 \\
\hline
\end{tabular}

${ }^{\mathrm{z}}$ The violet flower class includes bishops-violet $(V / V)$ and cobalt-violet $(V / v)$.

YThe white banner class includes the genotypes $w b$ V/-

Table 5. Segregation for flower color in $\mathrm{F}_{2}$ progenies from the allelism test cross between $V$ blu $\mathrm{BC}_{2} 5-593 \times \mathrm{F}_{3} V / v w b$.

\begin{tabular}{lccccccc}
\hline \hline & \multicolumn{3}{c}{ Flower color classes } & & & \\
& \multicolumn{7}{c}{ White } \\
Plot no. & Violet $^{2}$ & Blue & banner $^{\mathrm{y}}$ & White & $\begin{array}{c}\text { Ratio } \\
\text { tested }\end{array}$ & $\chi^{2}$ value & $P$ value \\
\hline $1-132^{\mathrm{x}}$ & 27 & 4 & 10 & & $9: 3: 4$ & 2.447 & 0.29 \\
$1-134^{\mathrm{x}}$ & 29 & 10 & 9 & & $9: 3: 4$ & 1.009 & 0.60 \\
$1-135^{\mathrm{x}}$ & 24 & 11 & 8 & & $9: 3: 4$ & 1.775 & 0.41 \\
$1-137^{\mathrm{x}}$ & 28 & 11 & 7 & & $9: 3: 4$ & 2.589 & 0.27 \\
$1-133^{\mathrm{w}}$ & 24 & 6 & 6 & 11 & $27: 9: 12: 16$ & 1.879 & 0.60 \\
$1-136^{\mathrm{w}}$ & 18 & 4 & 9 & 14 & $27: 9: 12: 16$ & 1.617 & 0.66
\end{tabular}

The violet flower class includes bishops-violet $(V / V)$ and cobalt-violet $(V / v)$.

yThe white banner class includes the genotypes $B l u /-w b$ and $b l u w b$.

'The totals for the violet, blue, and white banner classes were 108,36 , and 34 , respectively, and the $\chi^{2}(9: 3: 4)=3.303, P=0.19$.

wThe totals for the violet, blue, white banner, and white classes were 42 , 10,15 , and 25 , respectively, and the $\chi^{2}(27: 9: 12: 16)=1.396, P=0.71$.

1972). The genotype $w b v$ produces pure-white flowers, including the wings (Tables 1-4). Therefore, $w b$ cannot be a synonym for $r k^{d}$. Without experimental evidence, one cannot rule out the possibility that $w b$ may be another allele at the $R k$ locus, but this seems a highly improbable departure from the known effects of $r k$ and $r k^{d}$. An allelism test for that hypothesis would be very difficult to perform (perhaps impossible) because the red seed coat color of $r k$ and $r k^{d}$ is recessive and can only be classified reliably (expressed) with $b$ $v$ (Prakken, 1972), whereas the flower color pattern effects of $w b$ are not expressed with $v$. If $w b$ produced red seed coats with $b v$, it might be possible to develop a very indirect allelism test, but it would be very laborious to perform.

\section{Literature Cited}

Bassett, M.J. 1992. An induced mutant for blue flowers in common bean that is not allelic to $V$ or Sal and is linked to Fin. J. Amer. Soc. Hort. Sci. 117:317-320.

Bassett, M.J., L.B. Xue, and L.C. Hannah. 1990. Flower colors in common bean produced by interactions of the Sal and $V$ loci and a gametophyte factor $G a$ linked to Sal. J. Amer. Soc. Hort. Sci. 115:1029-1033.

Leakey, C.L.A. 1988. Genotypic and phenotypic markers in common bean, p. 245-327. In: P. Gepts (ed.). Genetic resources of Phaseolus beans. Kluwer, Boston.

Prakken, R. 1972. Inheritance of colours in Phaseolus vulgaris L. III. On genes for red seedcoat colour and a general synthesis. Med. Landb. Wageningen 72-29.

Royal Horticultural Society. 1938. Horticultural colour chart. The Royal Horticultural Society, London.

Smartt, J. 1970. Interspecific hybridization between cultivated American species of the genus Phaseolus. Euphytica 19:480-489. 